\title{
The Major Predictors for Prognosis of Tetanus Cases in Working Equines: Experience of Addis Ababa University, Ethiopia
}

\author{
Ayele Gizachew ${ }^{1}$, Hawi Jaleta ${ }^{1}$, Tadesse Birhanu ${ }^{1}$ and Josep Subirana ${ }^{2}$ \\ ${ }^{1}$ School of Veterinary Medicine, Wollega University, Post Box No: 395, Nekemte, Ethiopia \\ ${ }^{2}$ World Horse Welfare, Anne Colvin House, Snetterton, Norwich NR16 2LR, United Kingdom
}

\begin{tabular}{|c|c|}
\hline Abstract & Article Information \\
\hline $\begin{array}{l}\text { There is a paucity of information on tetanus in working donkeys and the clinical and therapeutic } \\
\text { factors that influence the prognosis of affected animals. The medical records of } 45 \text { working } \\
\text { donkeys admitted to the clinic for intensive treatment at College of Veterinary Medicine and } \\
\text { Agriculture, Addis Ababa University, Ethiopia, between } 2008 \text { and } 2009 \text { with a diagnosis of } \\
\text { tetanus were reviewed. The cases were grouped into survivors and non-survivors. The clinical } \\
\text { data of the two groups were compared using two-sample t-test and chi-square test. The } \\
\text { occurrence of tetanus in working donkeys in Ethiopia showed a distinct seasonality with a large } \\
\text { majority of cases being presented during the wet season. The overall survival rate was } 66.3 \% \text {. } \\
\text { For survivors the interval between the first clinical signs and recovery was } 19.00 \pm 3.50 \text { days. }\end{array}$ & $\begin{array}{l}\text { Article History: } \\
\text { Received : 25-01-2015 } \\
\text { Revised : 14-06-2015 } \\
\text { Accepted : 19-06-2015 } \\
\text { Keywords: } \\
\text { Donkey } \\
\text { Tetanus } \\
\text { Prognosis } \\
\text { Ethiopia }\end{array}$ \\
\hline $\begin{array}{l}\text { that treatment with tetanus antiserum did not improve the outcome. The major predictors of a } \\
\text { poor prognosis for working donkeys suffering from tetanus were the time between the first } \\
\text { clinical signs and hospitalization, the presence of complete trismus (lockjaw), dyspnoea, } \\
\text { drenching pneumonia and recumbency. } \\
\text { Copyright@2015 STAR Journal, Wollega University. All Rights Reserved. }\end{array}$ & $\begin{array}{l}\text { *Corresponding Author: } \\
\text { Ayele Gizachew } \\
\text { E-mail: } \\
\text { ayele thevet@yahoo.com }\end{array}$ \\
\hline
\end{tabular}

\section{INTRODUCTION}

Tetanus is caused by toxins produced by the grampositive, spore-forming anaerobic bacterium, Clostridium tetani (Weinstein, 1973; George, 1990). The disease is characterized by generalized muscular rigidity and spasms, hyperesthesia, convulsions, respiratory arrest and death (Ansari and Matros, 1982; George, 1990). Tetanus affects mammals worldwide, but the horse is reported to be the most susceptible domestic animal (Ansari and Matros, 1982; Green et al, 1994). Early diagnosis and therapeutic intervention is an imperative for any chance of survival. Despite advances in the understanding of the pathophysiology, there is no readily available diagnostic test that detects the presence of the toxin. The diagnosis is invariably based on the clinical signs and the history or presence of a wound, often, but by no means invariably, on the feet or limbs (Green et al, 1994).

Since routine vaccination of horses against tetanus was introduced, the incidence of this highly fatal disease has decreased dramatically (Green et al, 1994). However, equidae living in third world countries are seldom vaccinated and consequently tetanus is a relatively frequent clinical presentation (Kay and Knottenbelt, 2007).

The objective of this retrospective study was to describe the clinical course of tetanus in donkeys and to identify factors that could be useful as reasonably accurate predictors of prognosis and therapeutic decision making.

\section{MATERIALS AND METHODS}

\section{Animals and Study Design}

The medical records of 45 working donkeys diagnosed with tetanus upon presentation to the Addis Ababa University, College of Veterinary Medicine and Agriculture clinic in 2008/09 were reviewed. There were 25 males and 20 females ranging in age from 2 to 20 years. The diagnosis was based on the presentation of typical clinical signs of tetanus.

For each case, a full anamnesis and the findings of a physical examination were recorded. Special regard was paid to the history or presence of possible wounding. The treatment methods and the outcome were recorded. Based on the outcome, cases were divided into survivor and non-survivor (NS) groups.

\section{Treatment and Supportive Care}

All donkeys were treated with procaine penicillin (20000IU/kg) q12h. In addition 30,000 iu tetanus antiserum (TAT) was administered to 38 donkeys on admission. Wounds or foot abscesses were cleaned, debrided and flushed with saline, iodine, and hydrogen peroxide $(3 \% \mathrm{v} / \mathrm{v})$ as appropriate. Relaxation of the muscular tetany was attempted using acepromazine 
$(\mathrm{ACP})$ at an empirical dose rate and frequency sufficient to result in obvious muscle relaxation. The dose varied in individual cases from $0.03 \mathrm{mg} / \mathrm{kg}$ to $0.10 \mathrm{mg} / \mathrm{kg}$ and intervals varied between injections from $1-6$ hours.

The affected donkeys were placed in a darkened, quiet and well-bedded loose box to limit external stimuli that might disturb the animal and trigger tetanic spasms. Particular attention was paid to nursing support through quiet and gentle handling and plugging of the ears with cotton-wool. Intravenous polyionic fluids or stomach tubefeeding were provided during the critical stage when the animals were unable to eat and drink. Soft feeds and water were made readily accessible for those individuals who could eat and drink. Gentle manual evacuation of the rectum and urinary catheterization were performed in some donkeys to relieve discomfort.

\section{Statistical Analysis}

Descriptive statistics, two-sample t-test and chi-square test were performed using SPSS 15.0 for windows. For all tests the level of significance was set at $P<0.05$.

\section{RESULTS}

Hyperesthesia, elevated tail, flicking of the nictitating membrane on touch, extended head, stiff gait, dilated nostrils and erect immobile ears were the common clinical signs observed (figure 1). Trismus, dyspnoea and recumbency were also encountered in some animals.

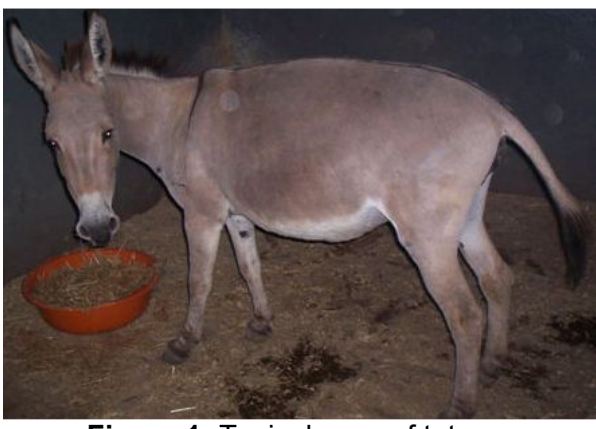

Figure 1: Typical case of tetanus

The mean time elapsed before presenting to the clinic had a significant effect on the outcome of affected cases (Table 1).

Table 1: Mean $\pm S D$ values of age, pulse rate, respiratory rate, temperature and number of days before hospitalization of the donkeys

\begin{tabular}{cccccc}
\hline & Range & $\begin{array}{c}\text { Survivors } \\
(\mathbf{N}=\mathbf{3 0})\end{array}$ & Non-survivors (N=15) & Total (N=45) & $\boldsymbol{P}$-value \\
\hline Age (year) & $2-20$ & $8.40 \pm 4.50$ & $10.30 \pm 4.70$ & $9.04 \pm 4.70$ & 0.213 \\
Pulse rate $(\mathrm{b} / \mathrm{m})$ & $36-80$ & $58.70 \pm 10.11$ & $58.30 \pm 12.30$ & $58.60 \pm 10.80$ & 0.90 \\
Respiratory rate $(\mathrm{r} / \mathrm{m})$ & $14-80$ & $42.50 \pm 17.00$ & $38.50 \pm 14.70$ & $41.20 \pm 16.20$ & 0.429 \\
Temperature $\left({ }^{\circ} \mathrm{C}\right)$ & $36-8.9$ & $37.50 \pm 0.60$ & $37.45 \pm 0.56$ & $37.49 \pm 0.60$ & 0.273 \\
Interval from clinical signs observed till & $1-9$ & $2.80 \pm 2.00$ & $4.57 \pm 2.22^{*}$ & $3.98 \pm 2.28$ & 0.011 \\
hospitalization (day) & & &
\end{tabular}

${ }^{*}$ Significantly different from mean value of the survivors group, $P<0.05$

Many animals had been drenched with herbal medicine by owners in an attempt to treat the disease and had developed aspiration pneumonia prior to admission.

The overall survival rate was $66.3 \% ; 33.3 \%$ of the cases died or were destroyed on human grounds. Age $(p=0.213)$ and sex $(p=0.352)$ had no significant effect on the outcome of the disease.
Complete trismus $(p=0.003)$, dyspnoea $(0.001)$ and recumbency $(0.000)$ were strongly associated with nonsurvival. Only one donkey (1/7) with aspiration pneumonia as a result of herbal and plant medicinal drenches survived (Table 2).

Table 2: The association of some of the factors with the outcome in 45 working donkeys treated for tetanus (2008/09), Ethiopia

\begin{tabular}{|c|c|c|c|c|}
\hline & Survivors & Non-survivors & Total & $\begin{array}{c}\text { P- } \\
\text { Value }\end{array}$ \\
\hline Sex & $\begin{array}{l}\text { Male: } 15(50 \%) \\
\text { Female: } 15(50 \%)\end{array}$ & $\begin{array}{l}\text { Male: } 10(66.7 \%) \\
\text { Female: } 5(33.3 \%)\end{array}$ & $\begin{array}{l}\text { Male: } 25(55.6 \%) \\
\text { Female: } 20(44.4 \%)\end{array}$ & 0.352 \\
\hline $\begin{array}{l}\text { Immunization } \\
\text { status (TAT) }\end{array}$ & $\begin{array}{l}\text { TAT: } 26(86.7 \%) \\
\text { No TAT: } 4(13.3 \%)\end{array}$ & $\begin{array}{l}\text { TAT: } 12(80.0 \%) \\
\text { No TAT: } 3(20.0 \%)\end{array}$ & $\begin{array}{l}\text { TAT: } 38(84.4 \%) \\
\text { No TAT: } 7(15.6 \%)\end{array}$ & 0.670 \\
\hline wound & $\begin{array}{l}\text { Wound: } 17(56.7 \%) \\
\text { No wound: } 13(43.3 \%)\end{array}$ & $\begin{array}{l}\text { Wound: } 10(66.7 \%) \\
\text { No wound: } 5(33.3 \%)\end{array}$ & $\begin{array}{l}\text { Wound: } 27(60.0 \%) \\
\text { No wound: } 18(40.0 \%)\end{array}$ & 0.376 \\
\hline Recumbancy & $\begin{array}{l}\text { Recumbent: } 7(23.3 \%) \\
\text { Not recumbent: } 23(76.7 \%)\end{array}$ & $\begin{array}{l}\text { Recumbent:15 (100\%) } \\
\text { Not recumbent:0 }(0 \%)\end{array}$ & $\begin{array}{l}\text { Recumbent:22 (48.9\%) } \\
\text { Not recumbent:23 (51.1\%) }\end{array}$ & 0.000 \\
\hline Dyspnoea & $\begin{array}{l}\text { Dyspnoea: } 4(13.3 \%) \\
\text { No dyspnoea: } 26(86.7 \%)\end{array}$ & $\begin{array}{l}\text { Dyspnoea: } 10(66.7 \%) \\
\text { Normal: } 5(33.3)\end{array}$ & $\begin{array}{l}\text { Dyspnoea:14 }(31.1 \%) \\
\text { Normal: } 31(68.9 \%)\end{array}$ & 0.001 \\
\hline Lock-jaw & $\begin{array}{l}\text { Completely Locked: } 3 \\
(10.3 \%) \\
\text { Not completely locked: } 27 \\
(90.0 \%)\end{array}$ & $\begin{array}{l}\text { Completely Locked: } 8 \\
(53.3 \%) \\
\text { Not completely locked: } 7 \\
(46.7 \%)\end{array}$ & $\begin{array}{l}\text { Completely locked: } 11 \\
(24.4 \%) \\
\text { Not completely locked: } 34 \\
(75.6 \%)\end{array}$ & 0.003 \\
\hline $\begin{array}{l}\text { Drenching } \\
\text { pneumonia }\end{array}$ & $\begin{array}{l}\text { Pneumonia: } 1(3.3 \%) \\
\text { No pneumonia: } 29(96.7 \%)\end{array}$ & $\begin{array}{l}\text { Pneumonia: } 6(40.0 \%) \\
\text { No pneumonia: } 9(60.0 \%)\end{array}$ & $\begin{array}{l}\text { Pneumonia: } 7(15.6 \%) \\
\text { No pneumonia: } 15(84.4 \%)\end{array}$ & 0.003 \\
\hline
\end{tabular}


The overall mean time between observation of the clinical signs by the owners and recovery was $20.00 \pm 4.50$ (range from 13 to 30 days). TAT administration was not significantly associated with outcome $(p=0.67)$. There was no significant difference in the mean time to recovery between those animals that received TAT (19.50 \pm 4.40$)$ and those without TAT $(21.00 \pm 1.00)(P=0.111)$.
On average the non-surviving donkeys died or were euthanized within 3 days after the first sign of tetanus was observed.

Most of the tetanus cases occurred during the long rainy season, June to September. The highest number of cases was recorded in June and July (Figure 2).

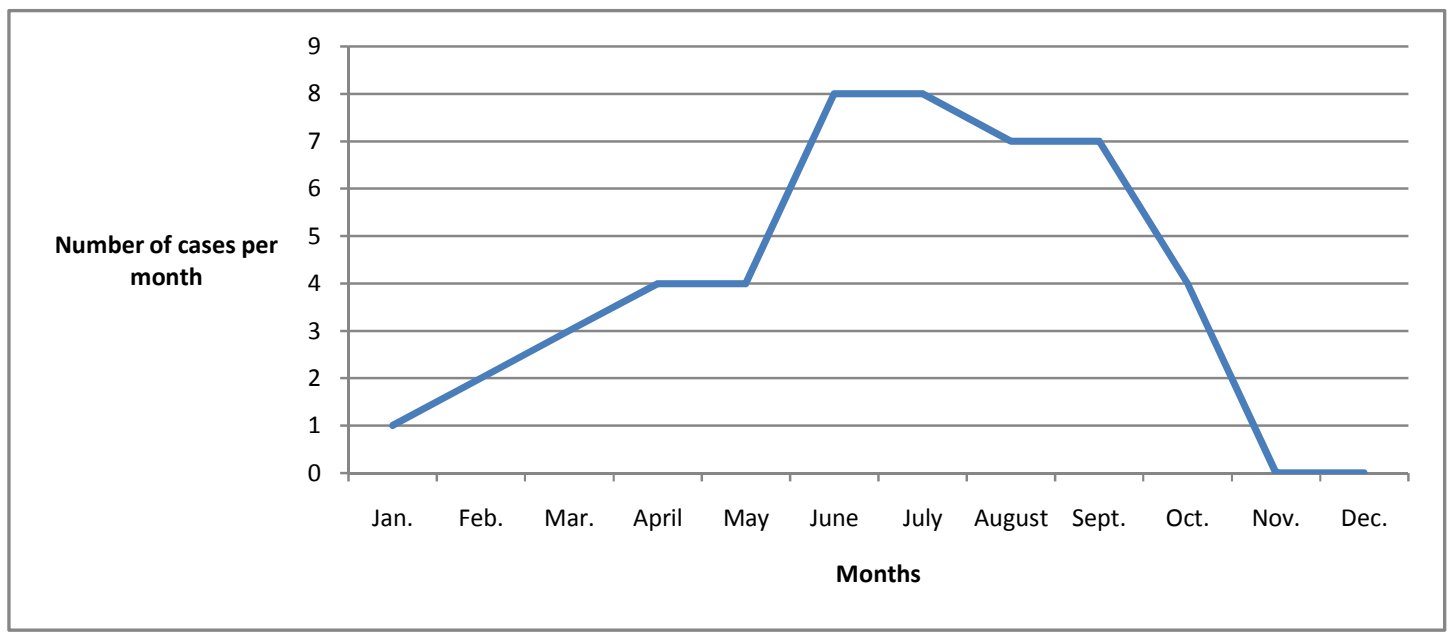

Figure 2: Cases of tetanus presented to the clinic in different months of the study period

\section{DISCUSSION}

This retrospective study confirmed that tetanus is one of the major fatal and infectious diseases of working donkeys in Ethiopia. In Morocco an overall survival rate of $46 \% \quad(n=56)$ was reported in working donkeys suffering from tetanus (Kay and Knottenbelt, 2007). This survival rate is lower than that of the present study. This may be attributed to the difference in treatment protocol, the grade of cases presented and the environment in which donkeys were kept. Prompt recognition and urgent access to veterinary attention is clearly major factors influencing survival. In the present study, cases could be presented at any time and the clinic was relatively convenient. Owner education in the recognition of the earliest signs had been in process for some years and this would be expected to result in earlier presentation and therefore a better prognosis. Most Ethiopian owners were able to recognize the condition but some of these were then tempted to try "treatments" that usually involved herbal drenches. The delays in presentation following this hope of a "cure" would probably result in a worse prognosis, even in the absence of aspiration pneumonia. Further education of owners in the dangers of delay and the particular dangers of using drenches is essential but the ingrained habits are necessarily hard to overcome even when treatment is offered free of charge.

Equidae that are appropriately vaccinated are solidly immune to the condition but vaccination is not commonly practiced in Ethiopia. The clinical course of the disease and the prognosis for survival will depend on the immune and vaccination status of the host, the dose of clostridial inoculation and resultant toxin production, and the duration and availability of the required aggressive treatment and supportive care (Beaty, 1987).

Age was not a predisposing factor for tetanus in the present study. Similar findings were reported in a retrospective study of 56 horses and donkeys (Beaty,
1987). However, it was reported that young horses were particularly vulnerable to tetanus (Galen et al., 2008). Age predisposition for developing tetanus should be investigated using case-control studies. It might reasonably be supposed that older horses might be more likely to be immune through natural exposure to the disease but this was not borne out in the present study. It seems that natural immunity from exposure is not as likely as might be supposed.

Tetanus antiserum is reported to be useful in binding free circulating toxin but it is accepted that toxin bound in the central nervous system is either not accessible to the antibody or the antibody is not capable of removing the toxin from the binding sites ( Rose and Hodgson, 1999). A study undertaken in Morocco showed that there was no association between the use of TAT and outcome even when high and /or repeated doses are used (Kay, 2006). Although fewer patients did not receive TAT in the present series, similar results were obtained. This suggests that tetanus antitoxin may neither as beneficial as is supposed nor economically justifiable in the treatment of tetanus, at least in working animals in the developing world (Kay, 2006). However, a larger sample size and a randomized, double-blind ended clinical trial is required to justify this tentative conclusion. The use of intrathecal tetanus antiserum has been proposed as means of improving the prognosis (Rose and Hodgson, 1999) but under the prevailing circumstances this could not be used.

The current study revealed that complete (fixed) trismus, dyspnea, recumbency, drenching pneumonia and a long time interval between the first clinical sign and hospitalization (veterinary attention) were strongly associated with a poor prognosis. A similar study revealed that dyspnoea and recumbency in equidae were indicators of poor prognosis (Galen et al., 2008). 
In the present study surviving donkeys recovered within 3 to 4 weeks after the first signs of tetanus were observed; this is consistent with other reports (Ansari and Matros, 1982, Galen et al., 2008). Neuronal binding of the tetanus toxin is irreversible and recovery requires regrowth of axon terminals and toxin destruction, which probably explains the time taken to achieve full recovery (Cook, 2001; Attygalle and Rodrigo, 2004). The first week appears to be a critical period for survival in working donkeys; non-surviving donkeys died or were euthanized 1 to 7 days after the first clinical sign was observed. Similar findings have also been reported previously (George, 1990; Galen et al., 2008). Recovery in all the cases here resulted in an ostensibly normal working animal without evidence of detectable neurologic deficits. Once recovered, the animals would be expected to be solidly immune and none of the cases presented in this study had apparently been affected previously.

The relatively high incidence of tetanus observed during the long rainy season might indicate an association of the disease with wet conditions. In the rainy season the feet of the donkeys becomes soft and are then probably more easily penetrated by sharp objects. In addition, mud sticks to the feet and this may support anaerobic conditions for the organism to replicate and produce its exotoxins. Additionally the wet season is the time of the year when land is ploughed increasing the chance for donkeys to sustain injury and infection.

\section{CONCLUSION}

This study indicates that the, time elapsed between first clinical signs and hospitalization, the presence of trismus, dyspnoea, drenching pneumonia and recumbency can be used as indicators of poor prognosis for tetanus in working donkeys.

\section{Conflict of Interest}

Authors declared no conflict of interest.

\section{REFERENCES}

Ansari, M.M., Matros, L.E. (1982). Tetanus. Compendium Continuing Education for Veterinarians 4: 473-479.

Attygalle, D., Rodrigo, N. (2004). New trends in the management of tetanus. Expert Review of Anti-infective Therapy 2: 73-84.

Beaty, H.N. (1987). Harrison's Principles of Internal Medicine. McGraw-Hill Book Company, New York.

Cook, T.M., Protheroe, R.T., Handel, J.M. (2001). Tetanus: a review of the literature. British Journal of Anesthesia 87: 477-487.

Galen, G.V., Delgusie, C., Sandersen, C., Verwilghen, D., Grulke, S., Amory, H. (2008). Tetanus in the equine species: a retrospective study of 31 cases. Tijdschrift voor Diergeneeskunde 133 (12): 512-517.

George, L.W. (1990). Large Animal Internal Medicine. Mosby, St Louis, MO.

Green, S.L., Little, C.B., Baird, J.D., Tremblay, R.R.M., Smith-Maxie, L.L. (1994). Tetanus in the Horse: A Review of 20 Cases (1970 to 1990). Journal of veterinary Internal Medicine 8: 128-132.

Kay, G. (2006). How useful is tetanus antitoxin in the treatment of equidae with tetanus? A comparison of three treatment protocols used in the management of 56 cases of equine tetanus presented to the SPANA clinics in Morocco in 2003-2004. In: Proceedings of an International Colloquium on working equines, Addis Ababa, Ethiopia, pp. 197.

Kay, Knottenbelt, D.C. (2007). Tetanus in equids: a report of 56 cases. Equine Veterinary Education 19: 107-112.

Muylle, E., Oyareat, W., Ooms, L., Decraemere, H. (1975). Treatment of tetanus in the horse by injection of tetanus antitoxin in to the subarachnoid space. Journal of American Veterinary Medical Association 167: 47-48.

Rose, R.J., Hodgson, D.R. (1999).Tetanus (Lock jaw). In Manual of equine practice. $2^{\text {nd }}$ edition, Saunders, USA, pp.544-545.

Weinstein, L. (1973). Current concepts: tetanus. New England Journal of Medicine 289: 1293-1296. 